\title{
28 Research Square \\ The quality of working life interferes in the bioethics in physicians-patient relationship
}

Mario Afonso Maluf ( $\square$ marioafonsomaluf@hotmail.com )

University of Porto

Rui Nunes

University of Porto

\section{Research Article}

Keywords: Quality of working life, Bioethics, Health service management, Public health, Medical law, Endomarketing, Quality of life, Burnout syndrome

Posted Date: February 8th, 2022

DOI: https://doi.org/10.21203/rs.3.rs-1309842/v1

License: (c) (1) This work is licensed under a Creative Commons Attribution 4.0 International License. Read Full License 


\section{Abstract}

\section{Background}

Bioethics and Quality of Working Life for physicians constitute direct relationship. This quantitative and qualitative research has shown a close relationship between the two. Through it we seek to demonstrate that aspects that involve their work can interfere in the person of the medical professional, also directly affecting their quality in the field to the relationship with the patient, essential basis for good medicine.

\section{Methods}

A structured questionnaire with topics pertinent to the context of the Quality of Working Life was sent from the Information Technology Department of the Federal Council of Medicine to the valid email addresses of 95,022 registered physicians (of the 451,777 who are active in Brazil) with a return of 426 units, $11 \%$ higher than the 383 needed to technically validate this research. The data presented were subsequently tabulated on the Excel spreadsheet, analyzed and concluded.

\section{Results}

Positive results were observed on average of the questions formulated where approximately $55 \%$ of the questions in which bioethics can be deconstructed from the context related to Quality of Working Life.

\section{Conclusions}

This study demonstrated with its positive results that, depending on the quality of work life, it also compromises more $50 \%$, the quality of bioethics in the physicians-patient relationship, a fundamental part of the foundation of medicine. Having a new look at the medical profession is fundamental for the patients as well. This case constitutes a public health problem, since almost $90 \%$ (89.3\%) of the Brazilian physicians are connected to this sector. These alarming results must be further explored and contextualized in studies carried out in other countries as well, focusing on health management, encompassing the vision in public health.

\section{Background}

Work is fundamental to people's lives and to nations, and its quality directly interferes with quality of life of all. The research proposes a new look at the relationship between the physicians-patient relationship and medical work, seeking an integrated and relational perspective that considers its operating conditions in its working environment and its reflection in the field of bioethics. Due to its very existence, the characteristics of medical services depend fundamentally on being a service provider based on the human factor. The problems that involve the entire context of human resource management, such as physical, cognitive, and organizational resources, are important to define the entire context of quality of life at work, or Quality of Working Life (QWL), for these professionals. Although the medical human factor is obviously not the only participant in a multiprofessional health team, it is certainly its main 
"coordinator"[1]. Since human resources (HR) are a nuisance and are often neglected in organizations, presenting positive potential or risk potential for them, they require a broad view that addresses good management in these services[2].

This article demonstrates a visceral connection with the very existence of the binomial of the physicianpatient relationship, fundamental in the practical work in medicine. A situation where the patients themselves identify those organizational aspects that can interfere in the physician-patient relationship[3].

The following question arises: can reasons that compromise the QWL interfere with in the bioethical decisions of the physician-patient relationship? Answers that we propose to seek and demonstrate the possible results in this scientific work.

In general, the service delivery sectors of organizations, such as medical services, are responsible for the direct and indirect production of fundamentally immaterial work[4].

The quality of these services depends directly on the mental and physical conditions of HR. "HR is the internal client of medical organizations[5]. Therefore, to achieve the desired results, it is necessary that health organizations develop specific strategies for HR[6]. As Kabene, Orchard, Howard, Soriano and Leduc[7] noted, adequate management of HR is essential to provide high-quality healthcare.

As socials beings, medical professionals are directly influenced by interactions with the world around them. These connection scan change professionals' culture, thinking, and (consequently) their way of acting. This accords with Vilarinho's[8] assertion, he said "man is understood as a historical being, who acts directly on reality, modifying it, and, concomitantly, modifying himself". Thus, their labor expression is intertwined with the impalpable concept of bioethics. This relationship is reflected within the relational space built by the continuous interaction of interpersonal constructs of thought and action. Their human expression in work locus is the mirror and reflection of these influences with personal intensities and "colors". Their work expression materializes through the fusion of medical praxis with the "object" of professional practice: that is, the patient. As Wallace, Lemaire, and Ghali[9] "[w]hen physicians are unwell, the performance of health-care systems can be suboptimum. Physician wellness might not only benefit the individual physician, but it could also be vital to the delivery of high-quality healthcare".

They face biological risks daily and are constantly subjected to stress and poor working conditions, this reality has been greatly intensified in this period of the pandemic by Covid-19. In addition, their work practice usually disregards the standard of most Brazilian workers' labor laws that respect a 26-hour rest period after 12 hours of uninterrupted work[10]. On November 9, 2009, during the Global Forum of Health Leaders in Taipei, Taiwan, World Medical Association President Dana Hanson spoke about a "silent desperation" among some physicians. "Physicians," he said, "should not have to choose between saving themselves and serving their patients," adding that "many physicians were inwardly burning"[11]. 
The most recent (and largest) survey conducted in Brazil, published in the Medical Demography of Brazil 2018 , confirmed this notion with the statements of " $82 \%$ of Brazilian physicians" who agreed that the main health problem in Brazil is poor management of medical services[12]. The QWL of medical professionals influences and determines the quality of physician-patient relationships. These relationships are fundamental to consolidating the provision of medical services, which also includes bioethical concepts and practices. "Quality of life" has also been taken over by organizations in general. QWL can be understood as a program aimed at facilitating and satisfying worker's needs, while developing their activities within the organization. Its fundamental idea is that people are more productive when they are satisfied with and involved in their work[13].

It is a great challenge that must come from improvements in medical organizations to improve endomarketing management. "We also address why health systems should routinely measure physician wellness as an indicator of health-system quality in view of the growing recognition that suboptimum physician wellness adversely affects system performance"[9].

\section{Methods}

This investigation was approved in its ethical aspects as unanimously by the Ethics Committee of the Faculty of Medicine of the University of Porto, and its methodology by the coordinator of the PhD in Bioethics at the same university.

The objective, identification and other data of this research are evidenced in the initial presentation of the emails and reiterated in the questionnaire, giving transparency to its reason.

All communication processes for this research project took place through a dedicated email address.

This work obtained the necessary authorizations for its realization by the Federal Council of Medicine (CFM); federal supervisory and regulatory body for Brazilian physicians; through its national directorate and entrusted to its Information Technology Department to carry out the process results from a security measure that aims to match the actual active electronic addresses with their corresponding physicians, that is, the authenticity of the medical relationship with their respective e-mail addresses.

A preliminary structured questionnaire was constructed, sent, and discussed with thirty other medical professionals, also through the same communication channel, with the aim of testing the form and content of the questions that should be formulated in a clear and understandable, making it if so a basic material of the proposed research. As part of this questionnaire, definitions of bioethics, ethics and medical deontology were introduced in its body to clarify possible doubts and standardize the concepts. The definitions also aimed to standardize and give security to the concepts of the theme. The research contains information, such as the anonymity of the participants, and guidelines for an exclusion from participating in the research in case of regret, which is requested by the same e-mail address as the research. This process was finally approved by the supervisor and the scientific work continued. 


\section{Participants}

In Brazil, it has more than 451,777 physicians[12], many of whom are part of this study.

After the supervisor's screening, the questionnaire was delivered to the Informatics Department of the CFM. Thereafter, it was sent via free software from Google Inc. to all physicians with a valid email on record. This totaled 95,022 professionals with active and correct e-mails with the Information Technology Department. By the end of the quantitative research, the Information Technology Department had received 426 filled questionnaires and shared the recorded results.

The research respects the normative criteria established by the National Health Council[14].

Quantitative analyzes were performed and the conclusions were drawn using the Excel program as an instrument for displaying the collected data, and the specific derivatives.

The questions were aimed at identifying distortions pertinent to the work environment, and human resource management related to aspects of QWL. The subjectivity, technical knowledge, and uniqueness of each response were weighed. The options contained in the questionnaire and explained in figures 3,4 , and 5 of the research, helped in the understanding between these factors that can qualify the physician's work environment and relate their results to the perceived commitment to bioethics in their professional relationship with patients.

\section{Sample}

The sample was drawn from over 450 thousand Brazilian physicians registered with the CFM. Using the formula below, a margin of error of $5 \%$ with a confidence level of $95 \%$ was defined. The confidence level of $95 \%$ corresponds to the health science area, this being the highest index for a quantitative research. The real population surveyed comprised the total of 95,022 of the more than 450 thousand registered physicians, where this number was defined by having concomitant valid correspondence between the physicians and his respective e-mail. Therefore, 95 thousand Brazilian physicians received the survey. The minimum sample to provide a reliable mathematical result is 383 fully completed questionnaires and controlled by the system. A return of 426 validated questionnaires was obtained in this survey $(11 \%$ more), which makes its result more robust. The formula for sample calculation was:

$n=\underline{N} \cdot Z^{2} \cdot p(1-p) . \quad Z^{2} \cdot p \cdot(1-p)+e^{2} \cdot(N-1)$

Where ' $n$ ' is the calculated sample, Nis the population, Zis the standardized normal variable associated with the confidence level, pis the actual event probability, and e is the sampling error.

\section{Results}

It was a victory to receive the completed questionnaires since the topic deals with a very delicate and personal issue for physicians. 
After collecting the return data their specific results will be shown below.

The first question formulated was "In which of the following medical areas do you work?".

In Brazil, 54 specialties were standardized by CFM Resolution No. 2,149[15]. They are included in clinical, surgical, diagnostic, and other areas (such as Hospital Administration and Auditing). Medical areas with clinical and surgical specialties represent almost the total return of the questionnaire sent, as presented in Figure 1.

The second question formulated was "How many years have passed since your graduation?". As shown in Figure 2, more than $80 \%$ of physicians have more than 10 years of medical degrees, data similar to the survey of the national Medical Census[16].

Regarding stress factors, the third question was "If tiredness and/or fatigue due to precarious working conditions (which can lead to stress) have been present at some point in your professional life, did these factors interfere with your ethical practices?". According to Figure 3, positive results were observed in $57.3 \%$ of physicians.

The fourth question was "If precarious physical, human, or support structures for the practice of medicine were present at some point in your professional life, did they interfere with your ethical practices?".

Considering the various challenges imposed by working environments, we can infer that insufficient QWL (such as lack of sleep) can cause distortions in bioethics. Lack of QWL is evident in excessive daily working hours and uninterrupted work. It is estimated that, in Brazil, " $89.6 \%$ of medical professionals work over 45 hours per week, and $16.65 \%$ work more than 80 hours per week"[5]. Similar data were found in Portugal, where " $89.7 \%$ of physicians who answered the questionnaires work more than 45 hours per week"[15]. Medical decisions require deep attention and careful reasoning. This pressure can lead medical professionals to experience burnout syndrome. Other studies found that about 40 to $60 \%$ of physicians have high levels of burnout in any given of their professional career and emergency physicians are most affected, presenting values between 46 and 93\%, according to values obtained in several studies[17] phase.

Similar studies found that " $47.8 \%$ of professionals had a high burnout score"[18]. These findings are consistent with the nation's largest survey of physicians. An alarming proportion (25\%) of physicians up to 35 years of age work more than 80 hours a week, and with $48.5 \%$ also working more than three consecutive shifts a week. In addition, only $21.7 \%$ of those who work on 24 -hour shifts have the next day off. The medical class has an exclusive dedication of $83.7 \%$ to medical activities[16].

Bulgarian healthcare suffers similar challenges. More than $50 \%$ of our responding physicians and nurses show moderate-to-high and very-high degree of burnout. Social and economic aspects of the burnout syndrome among medical professionals are reflected in reduced performance, low self-estimation, decreased quality of patient care, and in some cases, lower medical treatment effect[19]. As Mosadeghrad[20] reports in research, stress compromises QWL. 
For this study results are presented in Figure 4. Positive results observed in $56 \%$ of physicians.

The 2015 Medical Census profiled medical professionals. Analysis of the results showed that physicians' work was far from ideal. The organizations to which physicians belong "Do not offer an environment that brings to the individual comfort, respect, safety, and well-being, among others. In other words, the organization must provide an environment that is conducive to the use of their capabilities"[16]. Work directly affects the physicians' lives from a biopsychosocial perspective.

This work aims at presenting the factors that influence quality of working life in organizations. In this way, factors such as equal opportunities, task identity, fair remuneration, feedback, among others, are perceived as important[21].

In the services area, as the behavioral factor has an important role in several services, quality becomes even more critical. Approaches for HR management, human growth management, motivation, empowerment, endomarketing, among others, are items that must be included in the discussion agenda about service management[22].

As in other countries, QWL among Brazil's medical professionals has decreased substantially. Medical events held in Brazil have addressed the theme of burnout syndrome. Among these is the Ordinary General Assembly of the Ibero-American and Caribbean Medical Confederation (Assembleia Geral Ordinária da Confederação Médica Latina-Íbero-Americana e Caribe - Confemel) in Brasilia (Distrito Federal). Arthur Hengerer, Chair of the Federation of State Medical Boards [FSMB] of the United States of America (Conselhos Médicos dos Estados Unidos da América), emphasized and reaffirmed that this phenomenon does not occur only in Brazil. Physicians work increasingly under an enormous bureaucracy. They lack control of their environment which, traditionally, is already chaotic, as found by the Federal Council of Medicine (CFM). There is a lack of respect and equity and many conflicts of values. All this leaves the professionals very exposed, and the stress prevents them from deciding what is best for the patient[23].

It has been reported that a total of $45.8 \%$ of physicians complain of burnout syndrome[24]. Although physicians know the factors that lead to stress in their workplaces, as well as the prevention mechanisms, they are susceptible and, paradoxically, cannot prevent their physical and mental exhaustion. Burnout is especially problematic for individuals who are at the frontline of their professions. The impact of this chronic condition on physicians is particularly important given that their actions are linked to the mortality and morbidity of patients. The medical profession is acutely aware of this problem and many interventions have been developed to ameliorate the antecedents and consequences of burnout[25].

Physicians' responsibility for medical care in Brazil became more imposing after the ratification of the 1988 Constitution[26]. The state's obligation to the population's health is in Article 196 of the Brazilian Constitution[26]. Accordingly, the commitment to QWL became a critical point in the national health sector[26]. 
Regarding the fifth question the text was "If precariousness or lack of administrative action in health services were present at some point in your professional life, did it interfere with your ethical practices?". The results are presented in Figure 5. Positive results were observed in $55.7 \%$ of physicians.

Physicians are continually making significant investments in their professional lives. They face biological risks daily and are constantly subjected to stress and poor working conditions. In addition, their work practice usually disregards the standard of most Brazilian workers' labor laws that respect a 26-hour rest period after 12 hours of uninterrupted work[10]. On November 9, 2009 during the Global Forum of Health Leaders in Taipei, Taiwan, World Medical Association President Dana Hanson spoke about a "silent desperation" among some physicians. "Physicians," he said, "should not have to choose between saving themselves and serving their patients," adding that "many physicians were inwardly burning"[11].

In related research between the provider (physicians) and the Environmental Factors, such as health systems, HR and facilities, indicate that these are fundamentals for obtaining the quality of medical services provided[20]. Physicians seek to overcome organizational shortcomings that interfere with the quality of their care, which are conceptually structured in the physician-patient relationship[27].

It is evident that there is a direct relationship between good human resource management practices and medical professionals. The most recent (and largest) survey conducted in Brazil, published in the Medical Demography of Brazil 2018, confirmed this notion with the statements of " $82 \%$ of Brazilian physicians" who agreed that the main health problem in Brazil is poor management of medical services[12]. The QWL of medical professionals influences and determines the quality of physician-patient relationships.

"Quality of life" has also been taken over by organizations in general. This concept of quality in service management is also shared by Baathe[28]. Its fundamental idea is that people are more productive when they are satisfied with and involved in their work[13].

As a reference in this context that does not occur only in Brazil, we mention that even the United States, the largest nation in the world, problems with health management are present, causing many to have no access, and even quality medicine[29].

Certainly, the lack of quality in the management of medical services compromises and directly affects the quality of the services provided[30].

Improving QWL by avoiding wear, anxiety, and stress among medical workers can increase productivity in service provision. "We also address why health systems should routinely measure physician wellness as an indicator of health-system quality in view of the growing recognition that suboptimum physician wellness adversely affects system performance"[9].

\section{Discussion}

The results of this research, conducted with more than 95,000 physicians, should serve as a worldwide warning for the field of medicine, as they signal a close relationship between, health services 
management, QWL and bioethics. Being that the entire questionnaire formulated and delivered is focused on items pertinent to their work environment. Therefore, each physician's definition of the same questionnaire is an individual expression of his or her own feelings about the process.

The values measured in the quantitative survey are significant with $56.3 \%$ of data (on average) for the total positive results in the analyzed factors. Paying attention to the fact that here we repeat that $89.3 \%$ of Brazilian physicians have partial or total link with the public health system[16], therefore we consider this result of the research also a case of public health and medical law. In this context, factors that may compromise QWL are present in the environment surrounding physician-patient relationships. These factors may be capable of overriding bioethical precepts and practices.

There is no way to disassociate the human physician from the professional physician who manifests the practice of bioethics in the physician-patient relationship.

It is imperative to seek to implement several modern and consistent techniques that can be applied in the work environment of physicians, techniques that are pertinent in the path of the constant pursuit of improving the QWL of the medical profession.

There are several lines of work to improve QWL supported by big names in modern management that can be applied, which will favor not only due attention to the HR framework but also for general administration and improvement of the Quality of Life of employees.

It's time for a new look at the other side of this relationship also focused on the physicians.

Thus, we understand that the right of the patient; that we must have our love, welcome, dedication and the best of our technical knowledge; He cannot override the right of the physicians to have good working conditions for the exercise of good medicine.

\section{Conclusions}

Research can demonstrate significant results; where the positive mean value of 56.3\% (Figure 3, 4 and 5 ) has already been present at some point in their professional life; and these researched aspects are part of the medical work environment, such as the presence of stress, structural factors, and administrative support, compromise the QWL and also directly the physician-patient relationship in terms of bioethics, and as explained in the discussion above, in an obvious way, we reaffirm that the physician as a human being has the same needs as any other, despite his professional relationship being with a noble area the human health. The research has a new perspective, "The other side of the same coin." in context of bioethics.

Since the medical field is expansive, the Brazilian state is "the great employer" of the medical profession, with $89.3 \%$ of Brazilian physicians with exclusive or partial public ties. This is the case for $75 \%$ of all primary care physicians, $14.3 \%$ of whom work in public management, secondary care, or public universities[16]. Accordingly, a physician's QWL may help define the quality of patient care for an entire 
population. Therefore, we believe that with the results obtained and explained in a concise way below, this research can collaborate so that one can have a new look at the administration of medical human resources, mainly in the area of public health and medical law.

Research can demonstrate with significant positive results; average value of $56.3 \%$; those aspects that are part of the medical work environment, such as the presence of stress, structural factors, and administrative support, that compromise the QWL and also directly the physician-patient relationship in terms of bioethics.

\section{Abbreviations}

- Quality of Working Life (QWL)

- Human Resources (HR)

- Federal Council of Medicine (CFM)

\section{Declarations}

\section{Ethical Approval and Consent to participate}

This research was approved by the Ethics Committee of the Faculdade de Medicina da Universidade do Porto, document attached. For the approval of the individual participation of thousands of physicians, all the necessary explanations were explained in the body of the e-mail sent, with all the reasons and explaining the why of the research, which was also accompanied by the definitions of what was being questioned for a better understanding of the medical professionals in the text of the structured questionnaire to standardize the conceptual understanding. The very sending of the response to the structured opinion questionnaire represents your implicit approval to participate in the research. In cases where the physician did not want to participate in this survey, it was sufficient that the physician himself did not submit the questionnaire. In addition, the structured opinion survey contains a clarification that the participant can withdraw from having sent the questionnaire, regretting it, through the World Wide Web, simply by requesting its exclusion through this same communication channel, via the Internet, and a dedicated e-mail.

\section{Consent for publication}

Both authors consent to the publication of this article by the scientific journal Health and Quality of Life Outcomes.

\section{Availability of supporting data}

At any time the authors can make available the data required by the scientific journal Health and Quality of Life Outcomes. 


\section{Competing interests}

There is no conflict of interest of all those involved in the research.

\section{Funding}

There was no external funding.

\section{Authors' contributions}

Maluf MA: conceptualization, data curation, formal analysis, investigation, methodology, project administration, resources, software, supervision, validation, visualization, writing-original draft and writing-review and editing; Nunes R: methodology, supervision, validation and writing-original draft. All authors actively contributed to discussion of the results from the study and reviewed and approved the final version of the manuscript to be released.

\section{Acknowledgements}

I thank the Brazilian physicians who participated in the research, the Federal Council of Medicine of Brazil, symbolized in the figure of Dr. Hiran Gallo, the Informatics Department of the same council, and librarian Karyn M. Lehmkuhl.

\section{References}

1. Saar SR da C, Trevizan MA. Professional roles of a health team: a view of its components. Rev Lat Am Enfermagem [Internet]. 2007;15:106-12. Available from: http://www.scielo.br/scielo.php? script=sci_arttext\&pid=S0104-11692007000100016\&lng=en\&tlng=en

2. Bombiak E. Human resources risk as an apect of human resources management in turbulent environments. In: Pînzaru F, Zbuchea A, Brătianu C, Vătămănescu E-M, Mitan A, editors. Strateg Shift Major Challenges Today's Econ [Internet]. Bucharest; 2017. p. 121-32. Available from: https://www.dropbox.com/s/eb7f5ie9ydbl4mf/Volume Strategica 2017.pdf?dl=0

3. Doherty C, Stavropoulou C. Patients' willingness and ability to participate actively in the reduction of clinical errors: A systematic literature review. Soc Sci Med [Internet]. 2012;75:257-63. Available from: https://linkinghub.elsevier.com/retrieve/pii/S0277953612002808

4. Silva RR da. Importância do setor de recursos humanos no contexto de estratégia da organização [Internet]. [Orleans]: Centro Universitário Barriga Verde; 2013. Available from: http://www.uniedu.sed.sc.gov.br/wp-content/uploads/2015/02/Monografia-RAIANE-RODRIGUES-DASILVA.pdf

5. Maluf MAFE. Marketing de serviços na assistência médica: fatores que podem determinar a qualidade [Internet]. Universidade Presbiteriana Mackenzie; 1999. Available from: http://tede.mackenzie.br/jspui/handle/tede/4093 
6. Teixeira AF. A Importância dos recursos humanos na qualidade e efeitos no desempenho organizacional [Internet]. [Covilhã]: Universidade da Beira Interior; 2013. Available from: https://ubibliorum.ubi.pt/bitstream/10400.6/3085/1/Alexandra_Teixeira_M4566.pdf

7. Kabene SM, Orchard C, Howard JM, Soriano MA, Leduc R. The importance of human resources management in health care: a global context. Hum Resour Health [Internet]. 2006;4:20. Available from: https://doi.org/10.1186/1478-4491-4-20

8. Vilarinho YC. A influência social na formação do indivíduo: aproximações entre asteorias de Wilhelm Reich e de Lev Vygotski. Encontro Parana Encontro Bras Conv Bras [Internet]. Curitiba: Centro Reichiano; 2008. Available from: https://pt.scribd.com/document/73820744/Formacao-doindividuo\#

9. Wallace JE, Lemaire JB, Ghali WA. Physician wellness: a missing quality indicator. Lancet [Internet]. 2009;374:1714-21. Available from:

https://linkinghub.elsevier.com/retrieve/pii/S0140673609614240

10. Brasil. Consolidação das Leis do Trabalho: CLT [Internet]. Brasília: Senado Federal, Coordenação de Edições Técnicas; 2017. Available from:

https://www2.senado.leg.br/bdsf/bitstream/handle/id/535468/clt_e_normas_correlatas_1ed.pdf

11. The Lancet. Doctors get ill too. Lancet [Internet]. 2009;374:1653. Available from: https://linkinghub.elsevier.com/retrieve/pii/S0140673609619723

12. Scheffer M, Cassenote A, Guilloux AGA, Miotto BA, Mainardi GM. Demografia Médica no Brasil 2018 [Internet]. São Paulo: FMUSP, CFM, Cremesp; 2018. Available from: https://jornal.usp.br/wpcontent/uploads/DemografiaMedica2018.pdf

13. Arruda AT de, Dalpino CR, Nascimbem N de A, Tonon WF. A qualidade de vida nas organizações como fator influenciador na produtividade de seus colaboradores [Internet]. [Pederneiras]: Faculdade G \& P; 2016. Available from: https://www.fgp.edu.br/wp-content/uploads/2017/03/TCC-2016-Aqualidade-de-vida-nas-organizações-como-fator-influenciador-na-produtividade-de-seuscolaboradores.pdf

14. Brasil. Conselho Nacional de Saúde. Resolução n. 510, de 07 de Abril de 2016. Art.1, Parágrafos I, V e VII [Internet]. Brasília, Brasil; 2016. Available from: http://conselho.saude.gov.br/resolucoes/2016/Reso510.pdf

15. Costa ACMM da. Médicos, sono e qualidade de vida [Internet]. Universidade do Porto; 2012. Available from: https://repositorio-aberto.up.pt/handle/10216/71863

16. Scheffer M, Cassenote A, Poz MRD, Matijasevitch A, Castilho EA de. Demografia Médica no Brasil 2015 [Internet]. Cons. Fed. Med. e Cons. Reg. Med. do Estado São Paulo. 2015. Available from: http://demografiamedica.org.br/project/demografia-medica-no-brasil-2015/

17. Caramelo RFR. Síndrome de Burnout e a sua relação com o trabalho dos médicos [Internet]. Universidade do Porto; 2010. Available from: https://hdl.handle.net/10216/53383

18. Marôco J, Marôco AL, Leite E, Bastos C, Vazão MJ, Campos J. Burnout em profissionais da saúde Portugueses: uma análise a nível nacional. Acta Med Port [Internet]. 2016;29:24-30. Available from: 
https://www.actamedicaportuguesa.com/revista/index.php/amp/article/viewFile/6460/4534

19. Pavlova J, Afanasieva L, Deliyska B. Economic dimensions of burnout among medical professionals in Bulgaria. J Manag Mark Healthc [Internet]. 2011;4:247-53. Available from: http://www.tandfonline.com/doi/full/10.1179/1753304X11Y.0000000011

20. Mosadeghrad AM. Factors Affecting Medical Service Quality. Iran J Public Health [Internet]. 2014;43:210-20. Available from: http://www.ncbi.nlm.nih.gov/pubmed/26060745

21. Cavassani AP, Cavassani EB, Biazin CC. Qualidade de vida no trabalho: fatores que influenciam as organizações. XIII Simpep [Internet]. Bauru; 2006. p. 1-8. Available from: https://simpep.feb.unesp.br/anais/anais_13/artigos/784.pdf

22. Nóbrega KC. Gestão da qualidade em serviços [Internet]. [São Paulo]: Universidade de São Paulo; 1997. Available from: http://www.funecsantafe.edu.br/SeerFunec/index.php/forum/article/viewFile/820/806

23. Conselho Federal de Medicina. Suicídio, Síndrome de Burnout e dopping são debatidos em encontro das lideranças médicas latino-americanas e ibero-americanas [Internet]. Portal Médico. Brasília; 2016 [cited 2020 Mar 19]. Available from: http://portal.cfm.org.br/index.php? option=com_content\&view=article\&id=26580:2016-11-24-12-42-53\&catid=3

24. Burnout ganha destaque na agenda de conselhos. J Med [Internet]. Brasília: Conselho Federal de Medicina; 2017;31:2,7. Available from: http://www.flip3d.com.br/web/pub/cfm/? numero=265\&edicao=3874\#page/ 1

25. Montgomery A. The inevitability of physician burnout: Implications for interventions. Burn Res [Internet]. 2014;1:50-6. Available from: https://linkinghub.elsevier.com/retrieve/pii/S2213058614000084

26. Brasil. Seção II da saúde, Art. 196. Constituição da República Fed do Bras 1988 [Internet]. Brasília: Presidência da República, Casa Civil; 1988. Available from: http://www.planalto.gov.br/ccivil_03/constituicao/constituicao.htm

27. Hayes B, Fitzgerald D, Doherty S, Walsh G. Quality care, public perception and quick-fix service management: a Delphi study on stressors of hospital doctors in Ireland. BMJ Open [Internet]. 2015;5:e009564. Available from: https://bmjopen.bmj.com/lookup/doi/10.1136/bmjopen-2015009564

28. Baathe F, Rosta J, Bringedal B, Rø KI. How do doctors experience the interactions among professional fulfilment, organisational factors and quality of patient care? A qualitative study in a Norwegian hospital. BMJ Open [Internet]. 2019;9:e026971. Available from: https://bmjopen.bmj.com/lookup/doi/10.1136/bmjopen-2018-026971

29. Lee $P$, Khong P, Ghista DN. Impact of deficient healthcare service quality. Lee P, editor. TQM Mag [Internet]. 2006;18:563-71. Available from: https://www.emerald.com/insight/content/doi/10.1108/09544780610707075/full/html

30. Aguiar LK, Siman AG, Brito MJM. Endomarketing as a strategy of personnel management in health: a case study. Rev Enferm UFPE [Internet]. Recife; 2013;7:5490-9. Available from: 
https://periodicos.ufpe.br/revistas/revistaenfermagem/article/view/11834/14248

\section{Figures}

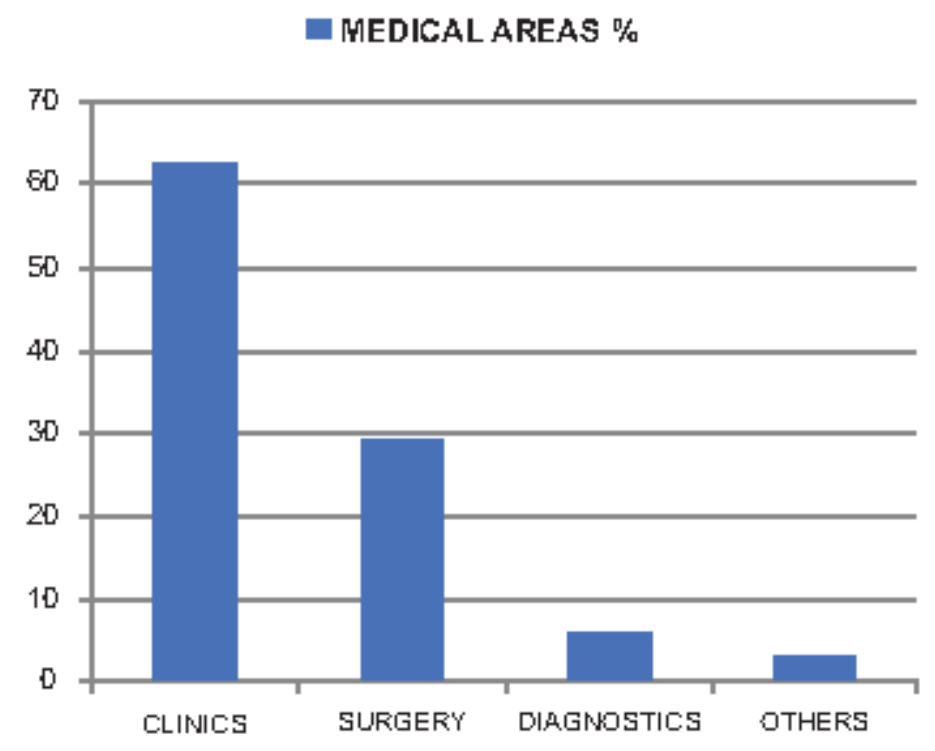

\section{Figure 1}

Physicians grouped by medical areas of specialty

- YEARS OF GRADUATION \%

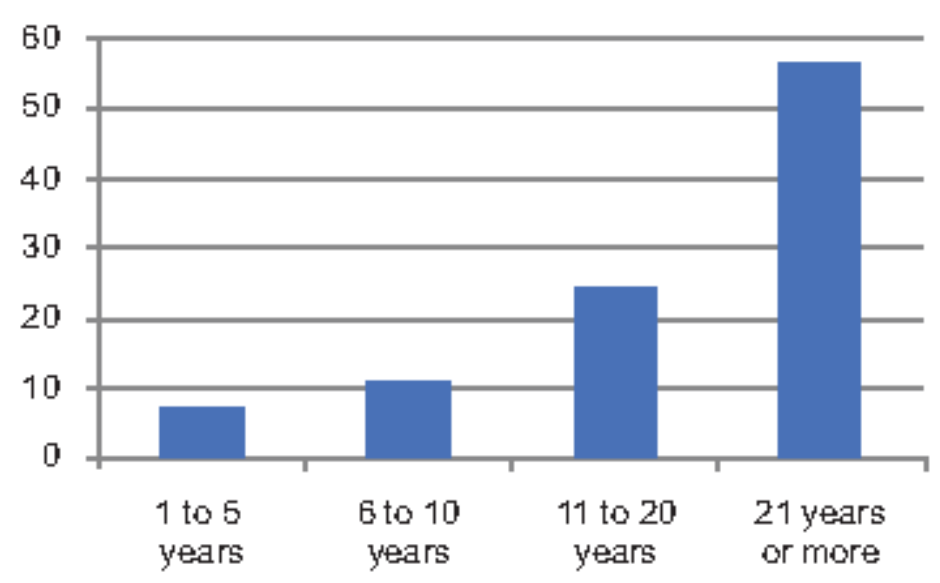

Figure 2

Physicians grouped by years of graduation 
DSTRESS FACTOR \%

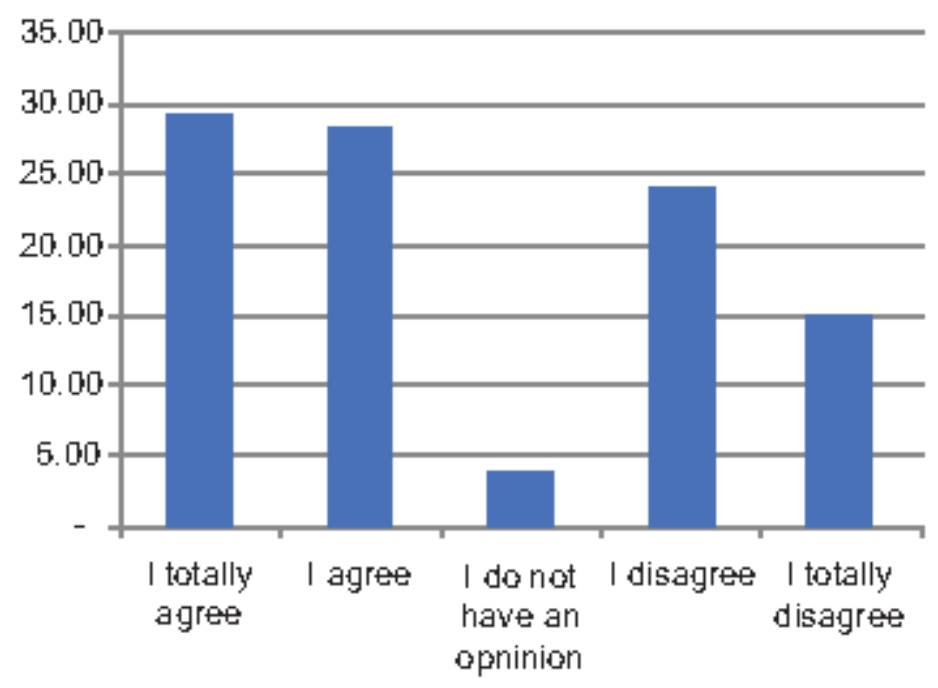

Figure 3

Stress Factor

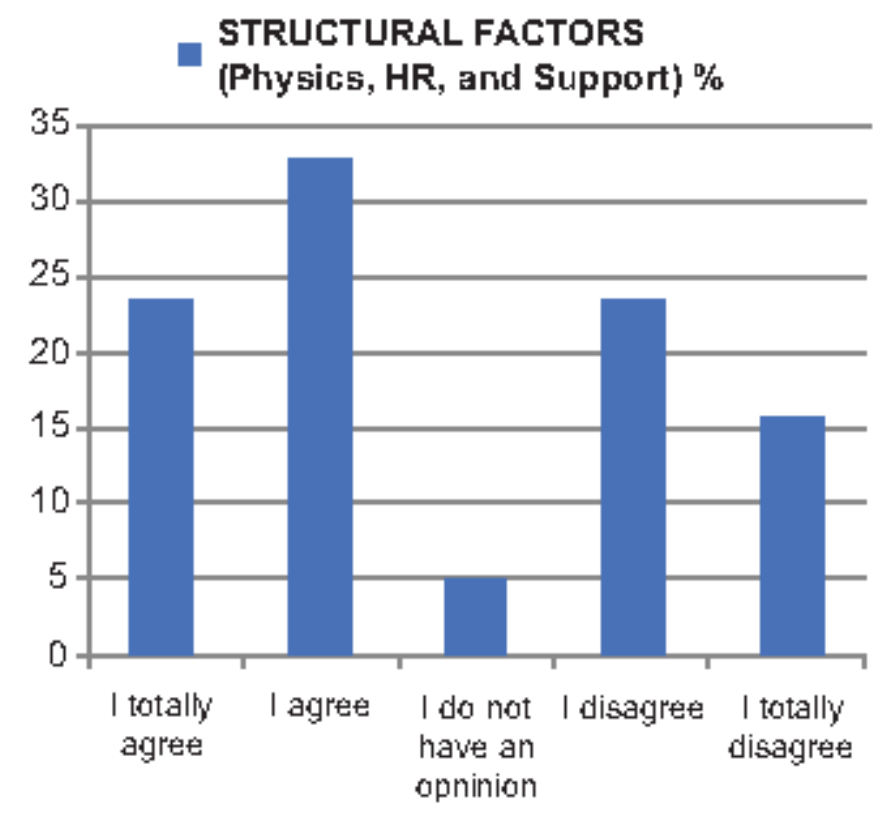

Figure 4

Structural Factors (Physical Structure, HR, and Support) 
EFAULT ADMINISTRATIVE ACTIONS \%

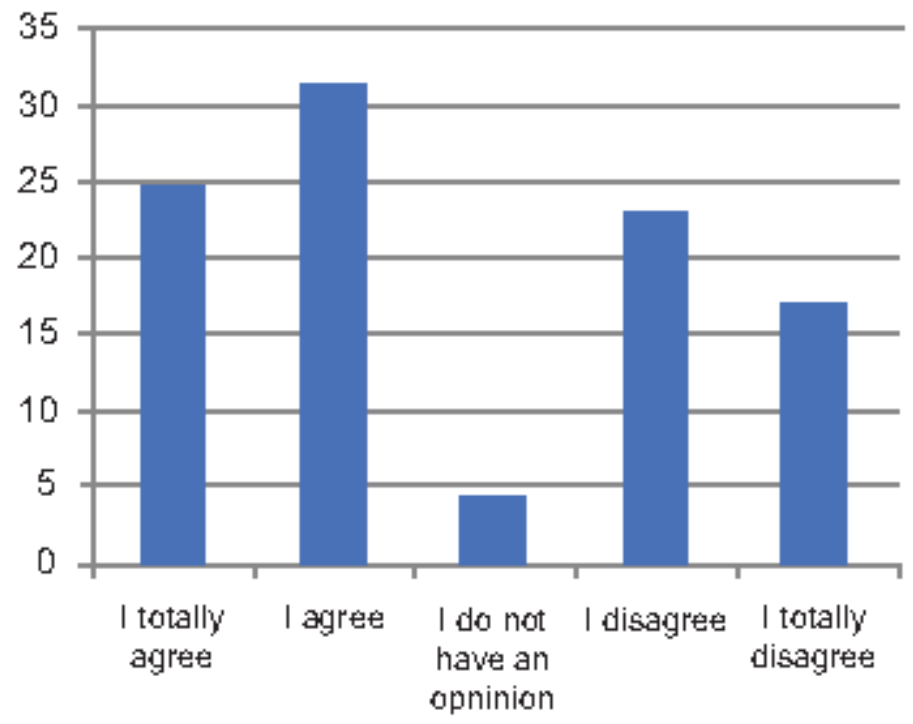

Figure 5

Fault Administrative Actions 